\title{
Perbandingan Administrasi Peradilan Dalam Keadaan Darurat (Judicial Emergency) Akibat Pandemi Covid-19 Di Amerika Serikat Dan Di Indonesia
}

\author{
Ibnu Sina Chandranegara \\ Fakultas Hukum Universitas Muhammadiyah Jakarta Indonesia \\ Jln. KH. Ahmad Dahlan, Cirendeu, Jakarta Selatan, 15419 Indonesia \\ ibnusinach@umj.ac.id
}

Received: 8 April 2020; Accepted: 26 Januari 2021; Published: 16 Maret 2021

DOI: 10.20885/iustum.vol28.iss1.art3

\begin{abstract}
The determination of a state of emergency affects not only the executive and legislative branches of power but also the judicial power. The public health emergencies due to Covid-19 Pandemic in various countries has a direct or indirect effect on judicial powers in carrying out their duties and functions. This article is intended to compare the application of judicial emergency in the United States and how it reflects on judicial power in Indonesia. This study uses the comparative constitutional law method, which is to compare the material of constitutional law and practice in other countries to take the best materials and practices and provide suggestions that should be avoided in positive constitutional law. This article concludes that there is a need for strict legal material in the law of judicial powers and the procedural law in Indonesia so that it does not delegate too much technical authority in dealing with emergencies in the judiciary.
\end{abstract}

Key Word: Judicial administration; procedural law; public health emergencies

\section{Abstrak}

Penetapan keadaan darurat jelas tidak hanya berdampak pada cabang kekuasaan eksekutif dan legislatif namun juga kekuasaan kehakiman. Penetapan keadaan darurat atas Pandemi Covid-19 di berbagai negara memiliki efek secara langsung maupun tidak langsung bagi kekuasaan kehakiman dalam melaksanakan tugas dan fungsinya. Artikel ini dimaksudkan untuk memperbandingkan penerapan judicial emergency di Amerika Serikat dan bagaimana refleksinya bagi kekuasaan kehakiman di Indonesia. Studi ini menggunakan metode perbandingan hukum tata negara, yaitu memperbandingkan materi hukum dan praktek hukum tata negara di negara lain untuk mengambil materi dan praktik yang terbaik dan memberikan saran yang perlu dihindari dalam hukum tata negara positif. Artikel ini mengambil kesimpulan bahwa perlunya materi hukum yang tegas dalam undangundang kekuasaan kehakiman dan kitab hukum acara di Indonesia sehingga tidak terlalu memberikan delegasi kewenangan mengatur secara teknis dalam mengadapi keadaan darurat di peradilan.

Kata-kata Kunci: Administrasi peradilan; hukum acara; keadaan darurat kesehatan 


\section{Pendahuluan}

Penetapan keadaan darurat oleh cabang kekuasaan eksekutif secara prinsip dapat dibedakan ke dalam dua bentuk. Pertama, keadaan darurat yang disebabkan oleh keadaan pemberontakan atau peperangan. Kedua, keadaan darurat yang disebabkan oleh terancamnya kesehatan umat manusia. ${ }^{1}$ Dalam keadaan demikian, David Davis mengemukakan "the government, within the Constitution, has all the powers granted to it, which are necessary to preserve its existence." 2 Hal ini menunjukan bahwa pemegang kekuasaan pemerintahanPresiden dalam konteks Indonesia -umumnya mempunyai kekuasaan untuk mengecualikan berlakunya hukum yang normal/biasa dengan memberlakukan hukum keadaan darurat. ${ }^{3}$ Apabila dikaitkan dengan bentuk sebagaimana diuraikan, maka dalam konteks yang pertama, Presiden dapat melakukan serangkaian tindakan dengan memberlakukan keadaan darurat dengan dasar prinsip hukum yaitu salus populi suprema lex (kepentingan umum adalah hukum tertinggi). Sedangkan dalam konteks yang kedua, Presiden akan memberlakukan serangkaian tindakan untuk menyelamatkan kesehatan warga negaranya atau dengan dasar prinsip hukum yaitu salus populi suprema lex esto (kesehatan masyarakat adalah hukum tertinggi). ${ }^{4}$ Kondisi ini jelas akan mempengaruhi relasi hubungan antara kekuasaan eksekutif dan legislatif. Umumnya kondisi ini akan mengaktifkan kekuasaan eksekutif tertentu dibidang legislasi melalui constitutional decree authority yaitu misalnya lahirnya peraturan pemerintah pengganti undang-undang di Indonesia, medidas provisorias (provisional measure) di Argentina atau bahkan decreto de necesidad y urgencia (decree of necessity and urgency) di Brazil. 5 Salah satu ciri khas dari kekuasaan ini adalah peraturan

\footnotetext{
${ }^{1}$ Nan D. Hunter, The Law of Emergencies Public Health and Disaster Management, Elsevier and Butterworth, New York 2017, hlm. 481.

2 William D Bader dan Frank J. Williams, "David Davis: Lawyer, Judge, and Politician in the Age of Lincoln”, Roger Williams University Law Review Vol. 14, No. 2, 2009, hlm. 197,

3 Sheeran, Scott P., "Reconceptualizing States of Emergency under International Human Rights Law: Theory, Legal Doctrine, and Politics", Michigan Journal of International Law, Vol. 34, 491, 2013, hlm. 490-491.

${ }^{4}$ Phoebe E. Arde-Acquah, "Salus Populi Suprema Lex Esto: Balancing Civil Liberties and Public Health Interventions in Modern Vaccination Policy," Washington University Journal Review, Vol. 7, No. 337 2015, hlm. 321.

${ }^{5}$ J. Mark Payne, Daniel Zovatto G., dan Mercedes Mateo Díaz, Democracies in Development: Politics and Reform in Latin America, Washington: Inter-American Development Bank, 2007, hlm. 112
} 
tersebut langsung berlaku efektif ketika diterbitkan tanpa melalui pembahasan di legislatif. 6

Pandemi Covid-19 memiliki karakter yang membatasi pergerakan manusia, disaat yang bersamaan, masyarakat memiliki hak untuk mengakses keadilan (access to justice) melalui peradilan. Sehingga kekuasaan kehakiman akan menerapkan keadaan darurat peradilan yang dikenal dengan istilah judicial emergency. Judicial emergency merupakan ketentuan yang dikenal di Amerika Serikat untuk pejabat pengadilan menetapkan keadaan darurat secara substansial yang dianggap membahayakan atau melanggar fungsi normal sistem peradilan, seperti kemampuan orang untuk memanfaatkan sistem peradilan, atau untuk memenuhi jadwal atau tenggat waktu yang ditetapkan oleh hukum acara. ${ }^{7}$ Hal ini menegaskan, terlepas kekuasaan kehakiman merupakan cabang kekuasaan yang penting untuk mengimbangi kekuasaan eksekutif maupun legislatif tidak hanya dalam keadaan normal, melainkan keadaan darurat. ${ }^{8}$ Ini disebabkan potensi banyaknya kebijakan yang dikeluarkan dalam keadaan darurat kesehatan yang berpotensi menyalahgunakan kewenangan maupun pelanggaran hak konstitusional warga negara. ${ }^{9}$ Dalam konteks Asia Tenggara saja, penanganan Covid-19 kerapkali pada akhirnya menciptakan pola pemerintahan yang otoriter. ${ }^{10}$ Oleh karena itu, kehadiran kekuasaan kehakiman yang merdeka dan tetap memberikan pelayanan keadilan menjadi kebutuhan yang perlu diperhatikan. ${ }^{11}$

${ }^{6}$ Gabriel L. Negretto, "Government Capacities and Policy Making by Decree in Latin America: The Cases of Brazil and Argentina", Comparative Political Studies, Vol. 37 No. 5, June 2004, hlm. 535.

${ }^{7}$ Federico Fabbrini, "The Role Of The Judiciary In Times Of Emergency: Judicial Review Of CounterTerrorism Measures In The United States Supreme Court And The European Court Of Justice." Yearbook of European Law, Vol. 28, No. 1, 2009, hlm. 664-697.

${ }^{8}$ David Pimentel, "Reframing the Independence v. Accountability Debate: Defining Judicial Structure in Light of Judges' Courage and Integrity,” Cleveland State Law Review Vol. 51, No. 1, 2015, hlm. 13-14.

9 Ibnu Sina Chandranegara, "Komparasi Kebijakan Hukum Dalam Penanggulangan Pandemi Penyakit Menular (Covid-19) Di Berbagai Negara: Penggunaan Keadaan dan Hukum Darurat atau Optimalisasi Instrumen Hukum yang ada?", dalam Ahmad Redi dan Ibnu Sina Chandranegara (editor), Segi Hukum Implikasi Covid-19, Prenada Kencana, Jakarta, 2020, hlm. 10

${ }_{10}$ Ibnu Sina Chandranegara, Diantara yang terbaik dan buruk dalam Merespon Covid-19 di Asia Tenggara, Makalah disampaikan dalam Seminar Nasional (via Zoom) "PSBB: Tanya Apa? Yang diselenggarakan Universitas Negeri Surabaya, tanggal 4 Mei 2020, hlm. 5-7

11 Ibnu Sina Chandranegata, Kemerdekaan Kekuasaan Kehakiman Pasca Transisi Politik, Radjawali Press, Jakarta, 2019, hlm. 312. 


\section{Rumusan Masalah}

Penelitian ini berpijak kepada dua permasalahan, antara lain: pertama, bagaimana perbandingan pelaksanaan administrasi peradilan dalam penerapan judicial emergency Amerika Serikat dan Indonesia dalam merespon Pandemi Covid-19 dan kedua, apakah manfaat yang dapat diambil bagi kekuasaan kehakiman di Indonesia dalam merespon kondisi yang seragam.

\section{Tujuan Penelitian}

Penelitian ini memiliki dua tujuan, antara lain: pertama, mengetahui persamaan dan perbedaan dari perbandingan pelaksanaan administrasi peradilan dalam penerapan judicial emergency Amerika Serikat dan Indonesia dalam merespon Pandemi Covid-19 dan kedua, menemukan manfaat yang dapat diambil bagi kekuasaan kehakiman di Indonesia dalam menghadapi kondisi yang serupa dikemudian hari.

\section{Metode Penelitian}

Penelitian ini merupakan penelitian yuridis normatif dengan pendekatan perbandingan hukum. Merujuk kepada Mark Rheinstein, perbandingan hukum merupakan pemaparan berbagai hal mengenai cara memperlakukan hukum secara ilmiah dengan cara pengklasifikasian secara khusus atau deskripsi analitik dari penggunaan satu atau lebih sistem hukum positif. ${ }^{2}$ Pendekatan perbandingan hukum yang digunakan dalam penelitian ini yaitu menggunakan salah satu dari enam tipe pendekatan sebagaimana dikemukakan oleh Walther Hug yaitu melakukan kajian yang menganalisis solusi objektif dan sistematis yang ditawarkan berbagai sistem untuk suatu masalah hukum tertentu. ${ }^{13}$ Oleh karena itu, elemen yang diperbandingkan dalam penelitian ini adalah pengaturan

\footnotetext{
12 Max Rheinstein, "Comparative Law - Its Functions, Methods and Usages," Arkansas Law Review Vol. 22, No. 3, 1968, hlm. 415

${ }^{13}$ Enam tipe perbandingan hukum sebagaimana dikemukakan Walther Hug yaitu: "They may compare foreign systems with the domestic system with a view toward ascertaining likenesses and differences,or analyze objectively and systematically the solutions which the various systems offer for any given legal problem. They may investigate the causal relation between different systems of law or compare the several stages of various legal systems. In addition, those studies which endeavor to ascertain the evolution of specific legal institutions in various legal systems or to examine legal evolution generally according to periods and systems are included in the term comparative law." Walther, Hug. "The History of Comparative Law." Harvard Law Review, Vol. 45, No. 6, 1932, hlm. 1027.
} 
maupun kebijakan administrasi peradilan di Amerika Serikat dengan Indonesia dalam merespon situasi pandemi covid-19.

Penelitian ini dilakukan untuk memperbandingkan berbagai solusi objektif dan sistematis yang dipergunakan diantara kedua peradilan negara tersebut dan menganalisis pilihan kebijakannya atas satu persoalan yang sama yaitu keadaan darurat akibat Pandemi Covid-19. Terlepas adanya perbedaan sistem kekuasaan kehakiman dan bentuk negara diantara keduanya. Peneliti berpendapat bahwa dikarenakan yang diperbandingkan adalah administrasi peradilan, maka apabila meninjau model administrasi peradilan antara Amerika Serikat dan Indonesia adalah sama yaitu kategori autonomous model of court administration. Model ini digunakan di Amerika Serikat sebagaimana pendapat yang serupa digunakan oleh Natalie Fox, Jakub Firlus and Piotr Mikuli yang mengemukakan: ${ }^{14}$

"The autonomous model of court administration is based on the idea that the competence of court management and administration (court business) in general is assigned directly to the judiciary. Although popular at the level of high/supreme courts, this model is not very common as far as the lower instances are concerned. In this regard, it does not occur in any of the featured countries in this book; however, it is characteristic in the US."

Hal serupa juga dimiliki oleh Indonesia melalui Pasal 21 ayat (1) dan (2) UU No. 48 Tahun 2009 Tentang Kekuasaan Kehakiman untuk Mahkamah Agung dan Pasal 29 ayat (3) dan (4) UU No 48 Tahun 2009 Tentang Kekuasaan Kehakiman untuk Mahkamah Konstitusi yang menegaskan bahwa organisasi, administrasi, dan finansial diatur langsung oleh Mahkamah Agung maupun Mahkamah Konstitusi secara masing-masing.

Oleh karena itu, lingkup data yang digunakan adalah data sekunder yang meliputi bahan hukum primer dan sekunder berupa peraturan yang bermakna kebijakakan hukum baik berupa perintah pengadilan (judicial order), memorandum peradilan (judicial memorandum), atau keputusan pejabat pengadilan (judicial decree) di Amerika Serikat dalam merespon pandemi Covid-19 baik skala negara federal maupun negara bagiannya. Lalu bagi Indonesia adalah

\footnotetext{
${ }^{14}$ Natalie Fox, Jakub Firlus and Piotr Mikuli, Models of Courts Administration: An Attempt at a Comparative Review, Riset Project No. 2016/21/B/HS5/00445 yang dibiayai oleh National Science Centre (Polandia), 2017. DOI: $10.13140 /$ RG.2.2.12610.58562
} 
peraturan yang umumnya berupa surat edaran atau pengumuman yang diterbitkan secara resmi oleh Mahkamah Agung dan Mahkamah Konstitusi. Analisis data dilakukan dengan mensistematisasi data-data untuk selanjutnya data-data tersebut digunakan untuk mencari manfaat bagi kekuasaan kehakiman dalam merespon kondisi yang seragam di Indonesia.

\section{Hasil Penelitian dan Pembahasan}

\section{Keadaan Darurat Peradilan (Judicial Emergency) di Amerika Serikat}

Sistem keadaan darurat peradilan di Amerika Serikat diatur dalam Judicial Emergency Act 2004. Undang-undang ini memungkinkan pejabat peradilan yang berwenang untuk mendeklarasikan keadaan darurat peradilan dalam keadaan tertentu. Pejabat peradilan resmi adalah hakim agung, Mahkamah Agung negara bagian; hakim kepala pengadilan banding; seorang hakim kepala dari peradilan sirkuit, pengadilan tinggi negara atau pelaksana harian atau pelaksana tugas kepala pengadilan tersebut. ${ }^{15}$ Selain itu, darurat peradilan berarti keadaan darurat yang dinyatakan oleh gubernur mengenai darurat kesehatan masyarakat sebagaimana didefinisikan dalam hukum negara bagian atau federal; keadaan darurat lokal sebagaimana didefinisikan dalam hukum negara bagian; atau keadaan darurat serius lainnya, dan ketika ditentukan oleh pejabat peradilan yang berwenang bahwa keadaan darurat tersebut secara substansial membahayakan atau terhalang berfungsinya sistem peradilan secara normal, kemampuan orang untuk memanfaatkan sistem peradilan, atau kemampuan orang-orang yang berperkara atau orang lain untuk memiliki akses ke pengadilan atau untuk memenuhi jadwal atau tenggat waktu yang ditentukan oleh perintah pengadilan atau peraturan, undang-undang, atau administrasi aturan atau regulasi. ${ }^{16}$ Berdasarkan undang-undang tersebut, berikut rekapitulasi kebijakan

15 Section 3. Judicial Act 2004 As used in this Act: (A) "Authorized judicial official" means any of the following officials when acting with regard to his or her respective jurisdiction: (1) The [Chief Justice of the state Supreme Court]; (2) The [Chief Judge of the state Court of Appeals]; (3) A [chief judge of a state superior court judicial circuit] or (4) The replacement for or successor to any of the officials set forth in subparagraphs (1) through (3) of this paragraph, as determined by the applicable rules of incapacitation and succession, should such official become incapacitated or otherwise unable to act.

16 Section 3. (B): "Judicial emergency" means: (1) A state of emergency declared by the [Governor] under (2) A public health emergency under [insert citation]; (3) A local emergency under [insert citation]; or (4) Such other serious emergency when, as determined by an authorized judicial official, the emergency substantially endangers or infringes upon the normal functioning of the judicial system, the ability of people to avail themselves of the judicial system, or the ability of litigants or others to have access to the courts or to meet schedules or time deadlines imposed by court order or rule, statute, or administrative rule or regulation. 
peradilan di setiap negara bagian dalam hal pelaksanaan operasional peradilan pada masa pandemi Covid-19:

Rekapitulasi Judicial Order dalam Judicial emergency di Amerika Serikat Per 6 April $2020^{17}$

\begin{tabular}{|c|c|c|}
\hline No & Negara Bagian & Kebijakan \\
\hline 1 & Arkansas ${ }^{18}$ & $\begin{array}{l}\text { Any summonses for persons to participate in jury panels suspended } \\
\text { until June } 30 \text {. }\end{array}$ \\
\hline 2 & Connecticut ${ }^{19}$ & $\begin{array}{l}\text { All remaining open courthouses will be closed on Tuesday, April } 7 \text {, } \\
\text { 2020. Beginning on Tuesday, April 14, 2020, all courthouses will be } \\
\text { closed on Tuesdays and Thursdays until further notice. }\end{array}$ \\
\hline 3 & Illinois ${ }^{20}$ & $\begin{array}{l}\text { Supreme Court orders that the Chief Judges of each circuit may } \\
\text { continue trials until further order of the Supreme Court. }\end{array}$ \\
\hline 4 & Kansas $^{21}$ & $\begin{array}{l}\text { Restrictions on in-person proceedings and suspensions of jury trials } \\
\text { extended until further notice/order of the Chief Justice. }\end{array}$ \\
\hline 5 & North Carolina ${ }^{2}$ & $\begin{array}{l}\text { Restrictions on in-person proceedings and suspensions of jury trials } \\
\text { extended until June } 1 .\end{array}$ \\
\hline 6 & Massachusetts 23 & $\begin{array}{l}\text { Restrictions on in-person proceedings and suspensions of jury trials } \\
\text { extended until May 4. Supreme Judicial Court order provides "pre- } \\
\text { trial detainees who have not been charged with an excluded offense as } \\
\text { set forth in Appendix A are entitled to a rebuttable presumption of } \\
\text { release on personal recognizance, and a hearing within two business } \\
\text { days of filing a motion for reconsideration of bail and release..." }\end{array}$ \\
\hline 7 & Pennsylvania 24 & $\begin{array}{l}\text { Supreme Court declines to order inmate/prisoner release. Directs } \\
\text { "President Judges of each judicial district to coordinate with relevant } \\
\text { county stakeholders to ensure that the county correctional institutions } \\
\text { in their districts address the threat of COVID-19, applying the } \\
\text { recommendations of public health officials, including the CDC's } \\
\text { Interim Guidance on Management of Coronavirus Disease 2019 } \\
\text { (COVID-19) in Correctional and Detention Facilities (Mar. 23, } \\
\text { 2020)." }\end{array}$ \\
\hline 8 & Rhode Island ${ }^{25}$ & $\begin{array}{l}\text { Supreme Court ordered expedited hearing for } 52 \text { inmates to reduce } \\
\text { state prison population. }\end{array}$ \\
\hline 9 & South Carolina 26 & $\begin{array}{l}\text { Restrictions on in-person proceedings and suspensions of jury trials } \\
\text { imposed until further notice/order of the Supreme Court. }\end{array}$ \\
\hline
\end{tabular}

17 Data dihimpun dari Judicial Order (semacam surat edaran) disetiap negara bagian yang dipublikasikan melalui website peradilan disetiap negara bagian per 6 April 2020

18 https://www.arcourts.gov/sites/default/files/articles/COVID-19-PC-april-3.pdf, diakses pada tanggal 5 April 2020

${ }^{19}$ https://jud.ct.gov/COVID19.htm, diakses pada tanggal 5 April 2020

20 https://courts.illinois.gov/SupremeCourt/Announce/2020/040320.pdf, diakses pada tanggal 5 April 2020

21 https://www.kscourts.org/KSCourts/media/KsCourts/Orders/2020-PR-032.pdf, diakses pada tanggal 5 April 2020

22 https://www.nccourts.gov/news/tag/press-release/chief-justice-beasley-issues-order-postponingcourt-proceedings-until-june-1-2020, diakses pada tanggal 5 April 2020

${ }^{23}$ https://www.mass.gov/files/documents/2020/04/03/12926.pdf, diakses pada tanggal 5 April 2020

24 http://www.pacourts.us/assets/files/page-1305/file-8910.pdf, diakses pada tanggal 5 April 2020

25 https://www.courts.ri.gov/PDF/In $\% 20$ re $\% 20$ Request $\% 20$ for $\% 20$ Prison $\% 20$ Census $\% 20$ Control $\% 20$ (Order).pdf, diakses pada tanggal 5 April 2020 April 2020

26 https://www.sccourts.org/whatsnew/displaywhatsnew.cfm?indexID=2474, diakses pada tanggal 5 


\begin{tabular}{|c|c|c|}
\hline 10 & $\begin{array}{l}\text { Northern Mariana } \\
\text { Islands } \\
\text { (teritorities) }^{27}\end{array}$ & $\begin{array}{l}\text { Restrictions on in-person proceedings and suspension jury trials } \\
\text { imposed until June } 5 .\end{array}$ \\
\hline 11 & West Virginia28 & $\begin{array}{l}\text { Restrictions on in-person proceedings and suspensions of jury trials } \\
\text { extended until May } 4 .\end{array}$ \\
\hline 12 & Alabama 29 & $\begin{array}{l}\text { Restrictions on in-person proceedings and suspensions of jury trials } \\
\text { extended until April } 30 .\end{array}$ \\
\hline 13 & Alaska $^{30}$ & $\begin{array}{l}\text { All trial court proceedings and civil marriage ceremonies are } \\
\text { suspended through May 1, .2020, except those priority hearings } \\
\text { identified in the Special Order of the Chief Justice. Civil cases. All } \\
\text { attorneys, parties, witnesses, and other participants shall appear by } \\
\text { telephone or videoconference. Criminal cases: All attorneys, parties, } \\
\text { witnesses, and other participants shall appear by telephone or } \\
\text { videoconference, except for evidentiary hearings and sentencings. }\end{array}$ \\
\hline 14 & Arizona 31 & $\begin{array}{l}\text { it is ordered that all in-person proceedings in all arizona appellate, } \\
\text { superior, justice and municipal courts and before the presiding } \\
\text { disciplinary judge be avoided to the greatest extent possible consistent } \\
\text { with core constitutional rights until further order of this court. It is } \\
\text { further ordered that empanelling of new petit juries scheduled for } \\
\text { march } 18,2020 \text { through April 17, } 2020 \text { be rescheduled. }\end{array}$ \\
\hline 15 & California $^{32}$ & $\begin{array}{l}\text { All jury trials are suspended and continued for } 60 \text { days. Courts may } \\
\text { conduct a trial at an earlier date upon finding of good cause shown or } \\
\text { through use of remote technology when appropriate }\end{array}$ \\
\hline 16 & Colorado 33 & $\begin{array}{l}\text { Effective immediately, all jury cases in state courts, with the exception } \\
\text { of jury calls for criminal trials facing imminent speedy trial deadlines, } \\
\text { are suspended through May 15, 2020, again excepting cases with } \\
\text { imminent speedy trial deadlines. }\end{array}$ \\
\hline 17 & Indiana ${ }^{34}$ & $\begin{array}{l}\text { None, Local: Emergency Petitions for Administrative Orders for Local } \\
\text { Courts to Operate }\end{array}$ \\
\hline 18 & Iowa $a^{35}$ & $\begin{array}{l}\text { Civil trials suspended to April 20. Criminal trials not yet commenced } \\
\text { suspended to April } 20 .\end{array}$ \\
\hline 19 & Kentucky ${ }^{36}$ & $\begin{array}{l}\text { Supreme Court issues new amendments to order limiting in-person } \\
\text { court proceedings, extends restrictions to April } 24\end{array}$ \\
\hline 20 & Louisiana $^{37}$ & All jury trials, both civil and criminal, scheduled to commence in any \\
\hline
\end{tabular}

${ }^{27}$ http://nmijudiciary.com/wp-content/uploads/2020/04/Covid-Order-No2-1.pdf, diakses pada tanggal 5 April 2020

28 http://www.courtswv.gov/covid19/JudicialEmergencyDeclaredAmendedOrder4-3-20.pdf, diakses pada tanggal 5 April 2020 2020

${ }^{29}$ http://www.alacourt.gov/docs/Administrative\%20Order\%20No.\%205.pdf, diakses pada tanggal 5 April

${ }^{30}$ https://public.courts.alaska.gov/web/covid19/docs/socj-2020-8131.pdf, diakses pada tanggal 5 April 2020

31 http://www.azcourts.gov/Portals/22/admorder/Orders20/2020-48.pdf, diakses pada tanggal 5 April 2020

32 https://newsroom.courts.ca.gov/internal redirect/cms.ipressroom.com.s3.amazonaws.com/262/

files/ 20202/Statewide $\% 20$ Order $\% 20$ by $\% 20$ the $\% 20$ Chief $\% 20 J u s t i c e C h a i r \% 20$ of $\% 20$ the $\% 20$ Judicial $\% 20$ Council\% 203-23-2020.pdf, diakses pada tanggal 5 April 2020

33 https://www.courts.state.co.us/userfiles/file/Media/SC\%20-\%20Cases\%20of\%20Interest/

Order\%20 Extending\%20Prohibition\%20on\%20Jury\%20Calls.pdf, diakses pada tanggal 5 April 2020

34 https://www.in.gov/judiciary/5575.htm, diakses pada tanggal 5 April 2020

35 https://www.iowacourts.gov/static/media/cms/Supervisory_order_of_3142020_22BCE0F4943C5.pdf, diakses pada tanggal 5 April 2020

36 https://kentucky.gov/Pages/Activity-stream.aspx?n=KentuckyCourtofJustice\&prId=164, diakses pada tanggal 5 April 2020

37 https://www.lasc.org/press_room/press_releases/2020/2020-04.asp, diakses pada tanggal 5 April 2020 
21 Maine $^{38}$

22 Maryland 39

23 Delaware (0 $^{40}$

24 Florida $^{41}$

25 Georgia $^{42}$

26 Hawaii $^{43}$

27 Idaho $^{44}$

28 Michigan $^{45}$

Louisiana state court between the date of this Order and March 27, 2020, are hereby continued to a date to be reset by local order no earlier than March 30, 2020. Civil and criminal jury trials that are in progress as of March 13, 2020 may continue to conclusion, in the discretion of the local court.

March 13 and continuing through May 1, 2020, with the exception of certain events, all in-person court events for family, civil, and criminal dockets are postponed.

All other matters scheduled to be heard between March 16, 2020, through May 1, 2020, are postponed pending further order of the Chief Judge of the Court of Appeals. All courts in the Maryland Judiciary, court offices, administrative offices, units of the Judiciary, and the Offices of the Clerks of the Circuit Courts and the clerks' offices of the District Court shall be restricted to emergency operations and closed with limited exceptions as described in this order beginning on March 17, 2020, through May 1, 2020, or until further order of the Chief Judge of the Court of Appeals.

Judicial emergency declared March 16 for 30 days. All trial courts in the State shall have the discretion to continue trials and hearings in civil and criminal cases for a period of 30 days in order to limit the number of people gathering in public court buildings.

All grand jury proceedings, jury selection proceedings, and criminal and civil jury trials are suspended during the period beginning Monday, March 16, 2020, through Friday, April 17, 2020, or as provided by subsequent order.

Judicial emergency declared. Decision left to local judges. "courts should remain open to address essential functions, and in particular courts should give priority to matters necessary to protect health, safety, and liberty of individuals."

with the exception of emergency and time- sensitive matters, in-person appearances for civil, family, and, to the extent possible, criminal dockets will be limited starting Tuesday March 17, 2020 until Thursday April 30, 2020, unless otherwise ordered.

Civil trials suspended until further notice. Criminal trials suspended March 25, 2020 through April 30, 2020.

n/a. "In support of this goal, on order of the Court, each trial court judge may implement emergency measures regarding court operations to enable continued service while also mitigating the risk of further transmission of the virus. Subject to constitutional and statutory

\footnotetext{
${ }^{38}$ https://www.courts.maine.gov/covid19.shtml, diakses pada tanggal 5 April 2020

39 https://www.courts.state.md.us/sites/default/files/admin-orders/20200325extendinglengthofrestricted operations.pdf, diakses pada tanggal 5 April 2020

40 https:// courts.delaware.gov/forms/download.aspx?id=120328, diakses pada tanggal 5 April 2020

41 https://www.floridasupremecourt.org/content/download/632431/7186205/AOSC20-17.pdf, diakses pada tanggal 5 April 2020

42 https://www.gasupreme.us/wp-content/uploads/2020/03/CJ-Melton-amended-Statewide-JudEmergency -order.pdf, diakses pada tanggal 5 April 2020

43 https://www.courts.state.hi.us/news_and_reports/2020/03/chief-justice-issues-order-limiting-incourt-proceedings, diakses pada tanggal 5 April 2020

44 https://isc.idaho.gov/EO/ISC-Emergency-Order-Ammended.pdf, diakses pada tanggal 5 April 2020

45 https://courts.michigan.gov/Courts/MichiganSupremeCourt/rules/court-rules-admin-matters/ Administrative\%20Orders/2020-08_2020-03-15_FormattedOrder_AO2020-1.pdf, diakses pada tanggal 5 April 2020
} 
29 Minnesota 46

$30 \quad$ Mississippi ${ }^{47}$

31 Missouri 48

32 Montana $^{49}$

33 Nebraska ${ }^{50}$

34 Nevada 51

35 New Hampshire ${ }^{52}$

36 New Jersey ${ }^{53}$

37 New Mexico 54 limitations, such emergency measures may include..."

For case types designated "Medium Priority" or "Low Priority" in the Limited Court Service Case Priorities List, all court proceedings (except jury trials currently underway, or cases where a speedy trial has been demanded) will be suspended for 14 days. No new jury trials in these case types should be scheduled for the next 30 days. In addition statewide order, ADM20-8001 Continuing Operations of the Courts of the State of Minnesota Under a Statewide Peacetime Declaration of Emergency. The order restricts in-person access to courthouses for only designated case types, and opens up additional opportunities for remote hearings that must occur during the COVID19 pandemic. The order goes into effect on Monday, March 23, 2020, and is in effect for the next 30 days or until another order is issued, whichever comes first.

Individual judges have discretion to control their general dockets and are authorized to instruct their clerks that jury summonses may not be sent to jurors which would be returnable to any date prior to April 13, 2020. No groupings of more than 50 people.

Restrictions on in-person proceedings and jury trials extended until May 1.

Mike McGrath, chief justice of the Montana Supreme Court, has instructed all state courts to adopt a list of practices beginning Monday. Parties set for trial through April 30 will be encouraged to request a postponement in order to minimize courthouse foot traffic.

None. Restrictions on those with or suspected of having COVID-19.

None

Subject to the exceptions in paragraph 4 below, all in-person proceedings in the Circuit, Superior and Supreme Courts are suspended from close of business on Monday, March 16, 2020 through April 6, 2020

As of March 18, 2020 and until further notice, there are no in-person Superior Court proceedings (except for extremely limited emergent matters and certain ongoing trials). As many matters as possible (including case management conferences, motions, and hearings) will be handled by telephone or video conference. Grand juries suspended until April 26. Other deadlines previously suspended or extended now extended to April 26.

Postponed civil jury trials that have not started, unless there are exceptional circumstances. Civil non-jury trials will proceed unless

\footnotetext{
46 http://www.mncourts.gov/mncourtsgov/media/CIOMediaLibrary/Administrative-OrderContinuing-the-Operations-of-the-Courts.pdf, diakses pada tanggal 5 April 2020

47 https://courts.ms.gov/appellatecourts/docket/sendPDF.php?f=700_490703.pdf\&c=91465\&a=N\&s=2, diakses pada tanggal 5 April 2020

48 https://www.courts.mo.gov/page.jsp?id=153953, diakses pada tanggal 5 April 2020

${ }^{49}$ https://courts.mt.gov/Portals/189/docs/COVID-19\%203-17.pdf, diakses pada tanggal 5 April 2020

50 https://supremecourt.nebraska.gov/sites/default/files/Administration/emergency/order3.12.20.pdf, diakses pada tanggal 5 April 2020

51 https://nvcourts.gov/, diakses pada tanggal 5 April 2020

52 https://www.courts.state.nh.us/supreme/orders/3-16-20-order.pdf, diakses pada tanggal 5 April 2020

53 https://www.njcourts.gov/courts/closings.html, diakses pada tanggal 5 April 2020

54 https://www.nmcourts.gov/uploads/FileLinks/a6efaf23676f4c45a95fdb3d71caea83/News_Release_ NM_Courts_to_remain_open_despite_school_closures.pdf, diakses pada tanggal 5 April 2020
} 
38 New York 55

39 North Dakota 56

40 Ohio $^{57}$

41 Oklahoma ${ }^{58}$

42 Oregon $^{59}$

43 South Dakota 60

44 Tennessee ${ }^{61}$

45 Texas $^{62}$

$46 \operatorname{Utah}^{63}$

47 Vermont 64

48 Virginia 65

49 Washington 66

50 Wisconsin $^{67}$

51 Wyoming 68 rescheduled by a judge. Jury summons limited to 25 people.

Local: Protection protocols in place.

Conclude current trials, but no new trials to begin. All non-essential functions postponed.

Effective immediately, all criminal [and civil] jury trials are suspended until April 24, 2020 or until further order of the Supreme Court.

None

Subject only to constitutional limitations, assigned judges should reschedule all non-jury trial settings, hearings, and pretrial settings.

Non-essential proceedings and most jury trials suspended until June 1. Presiding Judge directed to work with local law enforcement and community corrections to identify persons housed in their jails who can be safely released or are eligible for release.

None

All in-person proceedings in all state and local courts in Tennessee, including but not limited to municipal, juvenile, general sessions, trial, and appellate courts, are suspended from the close of business on Friday, March 13, 2020 through Thursday, April 30, 2020, subject to the exceptions.

n/a; order permits local courts to take steps until May 8, 2020.

n/a. Local courts authorized to take actions consistent with "Red" plan in state's continuity of operations plan.

Postponement of all jury trials for which the jury has not yet been drawn until at least April 15, 2020.

Restrictions on in-person proceedings and jury trials extended until April 26.

All jury trials shall be suspended until after April 24, 2020. All emergency matters that must be heard before April 24, 2020, must be heard by telephone, video, or other means that does not require inperson attendance, unless impossible. All criminal jury trials are suspended until after April 24, 2020

Supreme Court orders hold on jury trials, halts in-person proceedings statewide in favor of phone and video appearances through May 22.

Previous orders extended to May 31. Amended restrictions on in-

55 https://www.nycourts.gov/whatsnew/covid.shtml, diakses pada tanggal 5 April 2020 2020

56 https://www.ndcourts.gov/emergency-order-and-pandemic-response, diakses pada tanggal 5 April

${ }^{57}$ http://www.supremecourt.ohio.gov/coronavirus/default.asp, diakses pada tanggal 5 April 2020

58 http://www.oscn.net/images/news/SCAD-2020-24.pdf, diakses pada tanggal 5 April 2020

${ }^{59}$ https://www.courts.oregon.gov/courts/Pages/coronavirus.aspx, diakses pada tanggal 5 April 2020

60 https://ujs.sd.gov/uploads/news/JudicialEmergencyCOVID19.pdf, diakses pada tanggal 5 April 2020

61 http://tncourts.gov/sites/default/files/docs/order_-_2020-03-25t120936.486.pdf, diakses pada tanggal 5 April 2020

62 https://www.txcourts.gov/media/1446056/209042.pdf, diakses pada tanggal 5 April 2020

63 https://www.utcourts.gov/alerts/, diakses pada tanggal 5 April 2020

64 https://www.vermontjudiciary.org/sites/default/files/documents/ADMIN\%20DIR\%2036.pdf, diakses pada tanggal 5 April 2020

65 http://courts.state.va.us/news/items/2020_0327_scv_order_extending_declaration_of_judicial_ emergency.pdf, diakses pada tanggal 5 April 2020

${ }_{66}$ http://www.courts.wa.gov/content/publicUpload/Supreme $\% 20$ Court $\% 20$ Orders/Supreme $\% 20$

Court $\% 20$ Emergency\%20Order\%20re\%20CV19\%20031820.pdf, diakses pada tanggal 5 April 2020

${ }^{67}$ https://www.wicourts.gov/, diakses pada tanggal 5 April 2020 
person proceedings and jury trials order amended and reissued.

52 Washington, DC To the extent that a case type has not been identified below, all (federal district) ${ }^{69}$ nonpriority matters scheduled before May 1, 2020, will be rescheduled and new dates set; emergency matters will be heard as scheduled by the court and as set forth [in the order].

Berdasarkan rekapitulasi sebagaimana terurai, maka dapat di klasifikasi ke dalam berbagai kebijakan, antara lain:

\section{Penundaan kecuali menyangkut perlindungan kesejahteraan anak}

Terdapat beberapa pengadilan yang menunda seluruh proses persidangan kecuali beberapa negara bagian yang terus menjalankan proses peradilan yang menyangkut perlindungan anak maupun kesejahteraannya. ${ }^{70}$ Misalnya, terurai dalam Judicial Order Ketua Pengadilan Florida tanggal 17 Maret 2020

"All circuit and county courts shall continue to perform essential court proceedings, including but not limited to...juvenile dependency, shelter hearings; juvenile delinquency, detention hearings; hearings on petitions for temporary injunctions relating to safety of an individual...hearings on petitions for the appointment of an emergency temporary guardian..." 71

\section{Penundaan kecuali menyangkut perlindungan kekerasan dalam rumah tangga}

Pengadilan yang menunda seluruh proses persidangan kecuali beberapa negara bagian yang terus mengutamakan proses peradilan yang menyangkut perlindungan kekerasan dalam rumah tangga. ${ }^{72}$ Misalnya, terurai dalam Judicial Order Mahkamah Agung Alabama 13 Maret 2020:

68 http://www.courts.state.wy.us/wp-content/uploads/2020/04/COVID-19-Order.Extend.temp_.plan _.pdf, diakses pada tanggal 5 April 2020

69 https://www.dccourts.gov/sites/default/files/matters-docs/General\%20Order\%20pdf/AmendedOrder-5-14-20.pdf, diakses pada tanggal 5 April 2020

70 Negara bagian yang melakukan penundaan persidangan namun tetap menjalankan dalam hal perlindungan kesejahteraan anak antara lain: Alabama Supreme Court melalui Judicial Order Tanggal 13 Maret dan 16 Maret 2020, Alaska melalui Judicial Order Chief Justice tanggal 19 Maret 2020, Colorado melalui Judicial Order Chief Justice tanggal 16 Maret 2020, Delaware melalui Pengadilan Hukum keluarga Order tanggal 23 Maret 2020, Florida melalui Judicial Order Chief Justice tanggal 17 Maret 2020, Kansas melalui Judicial Order Chief Justice 18 Maret 2020, Judicial Order Mahkamah Agung di Louisiana tanggal 26 Maret 2020, Judicial Order Mahkamah Agung di Maine 13 Maret dan direvisi tanggal 18 Maret 2020, Judicial Order Mahkamah Agung Alabama 13 Maret 2020, Judicial Order di Connecticut tanggal 19 Maret 2020

71 https://www.floridasupremecourt.org/content/download/631996/7181425/AOSC20-15.pdf, diakses pada tanggal 5 April 2020

${ }^{72}$ Beberapa negara bagian yang menerapkan kebijakan Penundaan kecuali menyangkut perlindungan kekerasan dalam rumah tangga antara lain: Mahkamah Agung Alabama melalui Judicial Ordernya tanggal 13 Maret 2020 menyatakan: "Exceptions to this suspension of in-person court proceedings include...Proceedings related to protection from abuse... Orders of protection and temporary injunctions that otherwise expire between March 16, 2020, and April 16, are hereby extended until April 16, 2020, unless the court elects to enter an order to the contrary." Seluruh lingkungan peradilan di 
"Exceptions to this suspension of in-person court proceedings include...Proceedings related to protection from abuse... Orders of protection and temporary injunctions that otherwise expire between March 16, 2020, and April 16, are hereby extended until April 16, 2020, unless the court elects to enter an order to the contrary."73

\section{Penggusuran dan penyitaan}

Pengadilan yang menunda seluruh proses persidangan kecuali beberapa negara bagian yang terus melaksanakan proses peradilan yang menyangkut Penggusuran dan penyitaan. ${ }^{74}$ Misalnya terurai dalam Judicial Order Mahkamah Agung Pennsylvania 18 Maret 2020:

"In light of these circumstances, it is further Directed that, during the period encompassed by this Order or the judicial emergency, whichever is longer, no officer, official, or other person employed by the Pennsylvania Judiciary at any level shall effectuate an eviction, ejectment, or other displacement from a residence based upon the failure to make a rent, loan, or other similar payment. Nothing herein is intended to preclude requests for orders of possession resulting from judgments entered in landlord-tenant actions to be filed by mail. However, any execution on an order of possession is stayed to a date on or after April 3, 2020, subject to further orders. ${ }^{75}$

\section{Proses persidangan secara tatap muka sepenuhnya ditangguhkan}

Banyak pengadilan negara bagian yang menunda proses persidangan secara tatap muka sepenuhnya pada kategori ini. ${ }^{76}$ Misalnya, terurai dalam Judicial Order Mahkamah Agung Arkansas 17 Maret 2020:

Connecticut melalui judicial ordernya tanggal 19 Maret 2020 menyatakan: "Under the terms and provisions of the Judicial Branch's Continuity of Operations Plan (COOP), the courts will schedule and hear only those matters identified as "Priority 1 Business Functions"...Family orders of relief from abuse; Civil orders of relief from abuse; Civil protection orders..."

73 https://www.ncsc.org/ /media/Files/PDF/Newsroom/Coronavirus-Orders/ Domestic-violenceprotection-orders/Alabama\%203-13-2020\%20COV-19\%20order\%20FINAL.ashx, diakses pada tanggal 5 April 2020

74 Merujuk kepada judicial declaration Mahkamah Agung Maryland tanggal 18 Maret 2020 menyatakan:" Those foreclosures of residential properties and foreclosures of the rights of redemption of residential properties pending in the circuit courts shall be stayed effective immediately...Residential eviction matters pending in the District Court of Maryland and all pending residential eviction orders shall be stayed effective immediately...New foreclosure of residential property, foreclosure of rights of redemption after a tax sale, and residential evictions shall be stayed upon filing...". selanjutnya menurut Mahkamah Agung Pennsylvania dalam Judicial Ordernya tanggal 18 Maret 2020 menyatakan: "In light of these circumstances, it is further DIRECTED that, during the period encompassed by this Order or the judicial emergency, whichever is longer, no officer, official, or other person employed by the Pennsylvania Judiciary at any level shall effectuate an eviction, ejectment, or other displacement from a residence based upon the failure to make a rent, loan, or other similar payment. Nothing herein is intended to preclude requests for orders of possession resulting from judgments entered in landlord-tenant actions to be filed by mail. However, any execution on an order of possession is stayed to a date on or after April 3, 2020, subject to further orders."

${ }^{75}$ https://www.ncsc.org/ /media/Files/PDF/Newsroom/Coronavirus-Orders/Evictionsforeclosures/Pennsylvania \%203-18-2020\%20March\%2018\%20Supreme\%20Court\%20Administative $\% 20$ Order $\% 20$ Courts $\% 20$ Closed $\% 20$ to $\% 20$ the $\% 20$ Public $\% 20-\% 20008634$.ashx, diakses pada tanggal 5 April 2020

76 Selain Arkansas, Mahkamah Agung Alabama dalam judicial ordernya tanggal 13 Maret 2020 menyatakan: "The local and state courts of the State of Alabama are open and will remain open under all circumstances, subject to the provisions of this order... All in-person proceedings in all state and local courts in Alabama, including, but not limited to, proceedings in the circuit court, district court (including cases on the small claims docket), juvenile court, municipal court, probate 
"The courts of the State of Arkansas shall remain open. Nevertheless, pursuant to this Court's constitutional superintending authority to supervise the administration of the state judicial system, the Supreme Court of Arkansas hereby suspends all in- person proceedings in all appellate, circuit, and distict courts, subject to the exceptions in this order..."77

\section{Perintah untuk melepaskan tahanan kota}

Pengadilan yang menunda seluruh proses persidangan kecuali beberapa county (kabupaten) negara bagian seperti County of Harris di bawah Negara Bagian California, County of Ramsey dibawah negara bagian Minnesota dan County of Spokane di bawah negara bagian Washington yang terus melaksanakan proses peradilan yang memerintahkan untuk melepaskan tahanan kota (sanksi ringan). Sebagai contoh, misalnya terurai dalam Judicial Order Pengadilan Tinggi Sacramento 25 Maret 2020 di bahwa negara bagian California: ${ }^{78}$

"Because the parties agree that it is in the best interest of public health to reduce the population of the Sacramento County Jail System, and pursuant to Penal Code section 4004, the court finds good cause to order the Sacramento County Sheriff to utilize the authority granted in California Government Code section 8658 and Health and Safety Code sections 101029 and 120155, to release all confined persons identified and discussed herein who are serving county jail commitments with 60 actual days or less remaining on their sentence, condition of confinement, or other custody requirement from the date of this Order (March 25, 2020)."79

court, and appellate courts, are suspended beginning Monday, March 16, 2020 through Thursday, April 16, 2020, subject to the exceptions below...", diakses pada tanggal 5 April 2020

77 https://www.ncsc.org/ /media/Files/PDF/Newsroom/Coronavirus-Orders/In-person-proceedingsgenerally-suspended/Arkansas $\% 203-17-2020 \% 20$ Supreme $\% 20$ Court $\% 20$ of $\% 20$ Arkansas $\% 20$ Per $\% 20$ Curiam $\% 20$ RE\% 20Response\%20to\%20COVID-19\%20Pandemic.ashx, diakses pada tanggal 5 April 2020

${ }^{78}$ Selain Sacramento, diterbitkan release orders dibawah yurisdiksi Pengadilan Pidana Harris County tanggal 20 Maret 2020 menyatakan Effective immediately, upon identification by the Harris County District Attorney's Office and before the matter is placed on the Hearing Officers' docket, Harris County Pretrial Services is ORDERED to process the immediate release of the following persons under this General Order Bond to be supervised by Pretrial Services... selain itu, Pengadilan di Ramsey County juga menerbitkan release order tanggal 22 Maret 2020 yang pada pokoknya menyatakan: "Notwithstanding the terms of a defendant's current warrant of commitment, Ramsey County Correctional Facility Staff are authorized to release defendants on Electronic Home Monitoring as follows: (1) All Misdemeanor and Gross Misdemeanor offenses with the exception of [exceptions listed], (2) Felony offenses as follows [offenses listed], (3) Any defendant who does not qualify for release under paragraphs 1 and 2 above, may be placed on Electronic Home Monitoring as follows: [conditions listed]", diakses pada tanggal 5 April 2020

79 https://rbgg.com/wp-content/uploads/Dkt-6532-1-3JC-Ex.-1-14-of-Pls-Request-for-Judicial-Notice03-26-20-0489-3.pdf, diakses pada tanggal 5 April 2020 


\section{Perintah untuk pembebasan terdakwa yang ditahan. (penangguhan penahanan)}

Beberapa negara bagian mengambil kebijakan melepaskan tahanan. ${ }^{80}$ Ketua

Mahkamah Agung Kentucky (surat) 20 Maret 2020:

"As we take aggressive steps to ensure social distancing in our judicial facilities, Kentucky's overcrowded jails desperately need our attention. State and national media outlets are sounding the alarm about what a COVID-19 outbreak would do to inmates and jail staff and the law enforcement officers who come into contact with them. Much like nursing homes, jails are susceptible to worse-case scenarios due to the close proximity of people and the number of pre-existing conditions... We know what a potential disaster this could be and it's our responsibility to work with jailers and other county officials to safely release as many defendants as we can as quickly as we can." 81

\section{Tetap melaksanakan peradilan seperti biasa, namun menggunakan alat bantu telehearings dan teleconference}

Beberapa Pengadilan di beberapa negara bagian bahkan tidak menunda proses peradilan atau tahapan apapun melainkan beralih menggunakan telehearing dan teleconference. ${ }^{82}$ Misalnya terurai dalam Judicial Order Mahkamah Agung Arkansas 17 Maret 2020:

"All judges and court clerks are encouraged to utilize all available technologies including facsimile machines, e-mail, teleconferencing, and video conferencing- to continue handling judicial matters and further limit in-person courtroom appearances. Any criminal or civil rules that would impede a court clerk or judge's

80 Beberapa negara yang mengambil kebijakan pembebasan terdakwa yang ditahan antara lain: Mahkamah Agung Massachusetts melalui Judicial Order 3 April 2020, Michigan melalui pernyataan bersama Ketua Pengadilan dan Asosiasi Sherrif Tanggal 26 Maret 2020, Montana melalui Judicial Order Ketua Mahkamah Agung Montana tanggal 20 Maret 2020, New Jersey melalui Judicial Order Mahkamah Agung New Jersey 22 Maret 2020, Ohio melalui Judicial Order Mahkamah Agung Ohio tanggal 20 Maret 2020, Oregon melalui Judicial Order Ketua Mahkamah Agung Oregon tanggal 27 Maret 2020, Pennsylvania melalui Judicial Order Mahkamah Agung Pennsylvania tanggal 3 April 2020, South Carolina melalui Ketua Mahkamah Agung South Carolina melalui judicial order tanggal 16 Maret 2020, Tennessee melalui Mahkamah Agung Tennessee tanggal 25 Maret 2020

81 https://kcoj-my.sharepoint.com/personal/elizabethlucas_kycourts_net/_layouts/15/onedrive.aspx? originalPath $=\mathrm{aHR} 0 \mathrm{cHM}$ 6Ly9rY29qLW15LnNoYXJlcG9pbnQuY29tLzpmOi9nL3BlcnNvbmFsL2VsaXphYm V0aGx1Y2FzX2t5Y291cnRzX25ldC9FcU9wYzQwU2FPVktzUFhnZ192b2U4a0jxT0xCSIF2VDFrX3FWUjRX cm5NWER3P3J0aW11PWJZMmpNb3pSMTBn\&id=/personal/elizabethlucas_kycourts_net/Documents/KCO J\%20COVID19\%20Preparedness\%20\&\%20Response/01_Chief\%20Justice\%20Communication/20200320_Ti me $\% 20$ to $\% 20$ focus $\% 20$ on $\% 20$ looming $\% 20$ COVID $19 \% 20$ crisis $\% 20 \mathrm{in} \% 20$ Kentucky $\%$ E2\%80\%99s $\% 20$ overcro wded\%20jails.msg\&parent=/personal/elizabethlucas_kycourts_net/Documents/KCOJ\%20COVID19\%20Prep aredness\%20\&\%20Response/01_Chief\%20Justice\%20Communication, diakses pada tanggal 5 April 2020

82 Selain Arkansas, Mahkamah Agung Alabama juga menguraikan dalam Judicial Order tanggal 13 Maret 2020 bahwa: "Nevertheless, all judges and court clerks are urged to limit in-person courtroom contact as much as possible by utilizing available technologies, including electronic filing, teleconferencing, and videoconferencing. Any Alabama state or local rule, criminal or civil, that impedes a judge's or court clerks ability to utilize available technologies to limit in-person contact is suspended until April 16 , 2020.", diakses pada tanggal 5 April 2020 
ability to utilize such technologies are hereby suspended until Friday, April 3, 2020, and may be extended by order of this court as circumstances may warrant." 83

\section{Larangan memasuki area peradilan bagi yang telah terpapar coronavirus}

Beberapa Pengadilan di beberapa negara bagian bahkan tidak menunda proses peradilan atau tahapan apapun melainkan memerintahkan larangan kehadiran memasuki area peradilan bagi yang telah terpapar Covid-19.84 Misalnya, terurai dalam Judicial Order Ketua Pengadilan North Carolina 13 Maret 2020: "I further order that the clerks of superior court shall post a notice at the entrance to every court facility in their county directing that any person who has likely been exposed to COVID-19 should not enter the courthouse..." 85

\section{Menunda sesi persidangan juri}

Beberapa Pengadilan di beberapa negara bagian bahkan tidak menunda seluruh proses persidangan melainkan hanya menunda sesi persidangan juri (oral argumen). ${ }^{86}$ Misalnya, terurai dalam Judicial Order Pengadilan Tinggi Delaware 15 Maret 2020:

"All Civil and Criminal Jury Trials are suspended through and including April 15, 2020. Petit jury duty is suspended through and including April 15, 2020. Individuals summoned for petit jury duty during this time period are excused and should not appear. Grand Jurors should report as directed."

\section{Tidak menyatakan keadaan darurat sama sekali}

Terdapat setidak-tidaknya empat negara bagian hingga 6 April 2020 yaitu Michigan, Nevada, Ohio, South Dakota. Keempat-empatnya beranggapan bahwa

83 Semua hakim dan panitera didorong untuk memanfaatkan semua teknologi yang tersedia termasuk mesin faksimili, email, konferensi jarak jauh, dan konferensi video - untuk terus menangani masalah peradilan dan membatasi penampilan ruang sidang secara pribadi. Setiap aturan pidana atau perdata yang akan menghalangi kemampuan petugas pengadilan atau hakim untuk memanfaatkan teknologi tersebut dengan ini ditangguhkan hingga Jumat, 3 April 2020, dan dapat diperpanjang atas perintah pengadilan ini jika keadaan memungkinkan. https://www.ncsc.org/ /media/Files/PDF/Newsroom/Coronavirus-Orders/Requiring-telehearings-tele-conferences/Arkansas \%203-17-

2020\%20Supreme $\% 20$ Court $\% 20$ of $\% 20$ Arkansas $\% 20$ Per $\% 20$ Curiam $\%$ 20RE $\% 20$ Response $\% 20$ to $\% 20$ COVID19\%20Pandemic.ashx, diakses pada tanggal 5 April 2020

84 Selain North Carolina, Mahkamah Agung Oklahoma melalui Judicial Order tanggal 16 Maret 2020 menyatakan: "The following persons are probibited from entering any courtroom, court clerk's office, judges' offices, jury room or other facility used by the district courts [persons listed]..."

85 https://www.ncsc.org/ /media/Files/PDF/Newsroom/Coronavirus-Orders/Restricting-entranceto-courts/North\%20Carolina\%203132020\%20COVID1913March20207A39b2Order01.ashx, diakses pada tanggal 5 April 2020

${ }^{86}$ Selain delaware, Mahkamah Agung Hawaii juga menerbitkan Judicial Order tanggal 16 Maret 2020 yang menyatakan "All ongoing trials will be postponed to a date after Thursday, April 30, 2020...Civil trials and hearings will be postponed to a date after Thursday April 30, 2020... To the extent reasonably possible, criminal trials, grand jury proceedings, and hearings will be postponed to a date after Thursday, April 30, 2020..." 
sesuai denga maxim Fiat jūstitia ruat cælum dan beranggapan bahwa peradilan adalah penjelmaan kedaulatan tuhan atas representasi makna keadilan. ${ }^{87}$

\section{Administrasi Peradilan dalam Keadaan Darurat Pandemi Covid-19 di Indonesia}

Pemerintah Indonesia menetapkan keadaan darurat melalui Badan Nasional Penanggulangan Bencana (BNPB) dalam merespons Pandemi Covid-19.88 Tidak lama setelah itu, Presiden mengeluarkan Keputusan Presiden No. 7 Tahun 2020 Gugus Tugas Percepatan Penanganan Corona Virus Disease (COVID-19) menunjuk BNPB sebagai koordinator. Selanjutnya, merespon keadaan yang terus memburuk, Presiden mengeluarkan Keputusan Presiden No 11 Tahun 2020 tentang Penetapan Kedaruratan Kesehatan Masyarakat Corona Virus Disease 2019 (COVID-19) pada 31 Maret 2020. Di luar dari berbagai tindakan pemerintah dalam menetapkan keadaan darurat, respon tersebut dianggap tidak cepat, tidak tegas, dan terkesan gagap. ${ }^{89}$ Apabila merujuk sejarah ketika Pandemi Flu Spanyol tahun 1918 menerpa, Pemerintah Hindia Belanda bekerja buruk dalam menanggulanginya dan hanya bertumpu kepada Influenza Ordonnantie yang justru baru terbit pada 20 Oktober 1920 atau dua tahun setelah pandemi ini menyebar dari Eropa ke berbagai negara. Kondisi ini mengakibatkan banyak korban berjatuhan pada masa 1918-1920 di Hindia Belanda. 90

Oleh karena itu, Mahkamah Agung dan Mahkamah Konstitusi sebagai pelaku kekuasan kehakiman, merespon keadaan ini dengan cara yang berbeda hak ini disebabkan di Indonesia ketentuan Judicial Emergency tidak dimiliki dalam undang-undang kekuasaan kehakiman, meskipun demikian, banyak yang memaklumi disebabkan tidak pernah terjadi sebelumnya dalam sejarah peradilan di Indonesia. Mahkamah Agung misalnya, merespon keadaan darurat pandemi Covid-19 dengan menerbitkan Surat Edaran Sekretaris Mahkamah Agung (SE SEKMA) Nomor 1 Tahun 2020 tentang Penyesuaian Sistem Kerja Hakim dan

87 https://www.ncsc.org/ /media/Files/PDF/Newsroom/Coronavirus-News-Updates-Roundups/ Coronavirus $\% 20$ and $\% 20$ the $\% 20$ Courts $\% 20$ State $\% 20$ Profiles $\% 204-6-2020$ a.ashx, diakses pada tanggal 5 April 2020

88 Surat Keputusan Kepala BNPB Nomor 9.A. tahun 2020 berlaku selama 32 hari terhitung sejak tanggal 28 Januari - 28 Februari 2020. Diperpanjang dengan Surat Keputusan Kepala BNPB Nomor 13.A tahun 2020 yang berlaku selama 91 hari terhitung sejak tanggal 29 Februari - 29 Mei 2020.

${ }^{89}$ Ibnu Sina Chandranegara, Op. Cit., hlm 12

90 Siddharth Chandra, "Mortality from the influenza pandemic of 1918-1919 in Indonesia," Population Studies, Vol. 67, No. 2, 2013, hlm 185-193. 
Aparatur Peradilan Dalam Upaya Pencegahan Penyebaran COVID-19 di Lingkungan Mahkamah Agung RI dan Badan Peradilan di Bawahnya. SE SEKMA No. 1 Tahun 2020 dianggap tidak efisien dalam hal pendelegasian kewenangan dikarenakan Pimpinan Satuan kerja dalam mengambil tindakan maupun peraturan teknis yang diperlukan harus berkoordinasi dengan Sekretaris Mahkamah Agung. Akhirnya, untuk menata pengaturan yang masih belum dianggap efektif, maka SE SEKMA ditingkatkan menjadi SEMA dengan menerbitkan Surat Edaran Mahkamah Agung Nomor 1 tahun 2020 tentang Pedoman Pelaksanaan Tugas Selama Masa Pencegahan Penyebaran Corona Virus Disease 2019 (Covid-19) di Lingkungan Mahkamah Agung RI dan Badan Peradilan yang berada dibawahnya (SEMA No. 1 Tahun 2020) dengan batasan berlaku hingga 5 April 2020. Edaran ini dianggap bisa menjadi dasar pijakan bagi peradilan kaitannya dalam proses penegakan hukum yang lebih baik khususnya dalam merevisi SE SEKMA No. 1 Tahun 2020.

Terdapat pengklasifikasian menjadi empat bentuk kebijakan persidangan dalam SEMA No. 1 Tahun 2020.91 Pertama, persidangan perkara pidana, pidana militer, dan jinayat tetap dilaksanakan khusus terhadap perkara-perkara yang terdakwanya sedang ditahan dan penahanannya tidak dapat diperpanjang lagi selama masa pencegahan penyebaran Covid-19 di lingkungan MA dan badan peradilan di bawahnya. Kedua, persidangan perkara pidana, pidana militer, dan jinayat terhadap terdakwa yang secara hukum penahannya beralasan untuk diperpanjang, ditunda sampai berakhirnya masa penyebaran Covid-19. Penundaaan persidangan dapat dilakukan dengan hakim tunggal. Ketiga, terhadap perkaraperkara yang dibatasi jangka waktu pemeriksaan oleh ketentuan perundangundangan, hakim dapat menundanya walaupun melampaui tenggang waktu pemeriksaan yang dibatasi oleh ketentuan perundang-undangan dengan perintah kepada panitera pengganti agar mencatat dalam Berita Acara Sidang adanya keadaan luar biasa. Keempat, dalam hal terdapat perkara-perkara yang tetap harus disidangkan, maka (1) penundaan persidangan dan pembatasan pengunjung sidang merupakan kewenangan majelis hakim menentukan; (2) majelis hakim dapat

91 Poin 2 Huruf a, b, c, d, e Surat Edaran Mahkamah Agung Nomor 1 Tahun 2020 tentang Pedoman Pelaksanaan Tugas Selama Masa Pencegahan Penyebaran Corona Virus Disease 2019 (Covid-19) di Lingkungan Mahkamah Agung RI dan Badan Peradilan yang berada dibawahnya 
membatasi jumlah dan jarak aman antar pengunjung sidang (social distancing); (3) Majelis Hakim dapat memerintahkan pendeteksian suhu badan serta melarang kontak fisik seperti bersalaman bagi pihak-pihak yang akan hadir ataupun dihadirkan di persidangan; (4) Majelis hakim maupun pihak-pihak dalam persidangan dapat menggunakan alat pelindung berupa masker dan sarung tangan medis sesuai dengan kondisi dan situasi persidangan. (5) Pencari keadilan dianjurkan untuk memanfaatkan aplikasi e-litigation untuk perkara perdata, perdata agama dan tata usaha negara. Selain itu, kewajiban untuk berkoordinasi dengan Sekretaris Mahkamah Agung dalam hal pimpinan satuan kerja untuk menyusun kebijakan teknis menjadi dihapuskan. Selain itu SEMA No. 1 Tahun 2020 sendiri memiliki batas keberlakuan yaitu hingga pada 5 April 2020.

Ketentuan SEMA No. 1 Tahun 2020 telah mendapatkan perpanjangan masa berlakunya dua kali hingga saat ini melalui SEMA No. 2 Tahun 2020, SEMA No. 3 Tahun 2020 dan SEMA No. 3 Tahun 2020. Tiga kali perubahan SEMA No. 2 Tahun 2020 memperpanjang berlakunya SEMA No. 1 Tahun 2020 menjadi hingga 21 April 2020, SEMA No. 3 Tahun 2020 memperpanjang berlakunya SEMA No. 1 Tahun 2020 menjadi hingga 13 Mei 2020, dan SEMA No. 4 Tahun 2020 memperpanjang berlakunya SEMA No. 1 Tahun 2020 menjadi hingga 29 Mei 2020. Dalam hal administrasi peradilan, MA melakukan optimalisasi Peraturan Mahkamah Agung No. 1 Tahun 2019 tentang Administrasi Perkara di Pengadilan secara Elektronik. Dalam hal pelaksanaan administrasi persidangan menggunakan aplikasi e-Court sedangkan untuk pelaksanaan persidangan menggunakan aplikasi e-Liltigation. Aplikasi e-Litigation hanya ditujukan pada persidangan perkara Perdata di Pengadilan Negeri, Perdata Agama di Pengadilan Agama dan Tata Usaha Negara di Pengadilan Tata Usaha Negara. Hal ini dikarenakan dalam perkara-perkara tersebut tidak melibatkan terdakwa yang sedang ditahan atau perkara pidana, karena melibatkan terdakwa yang sedang masa penahanan. Perkara Pidana tetap digelar secara konvensional dengan menghadirkan para pihak di ruang persidangan sesuai dengan prosedur protokol kesehatan pencegahan COVID-19.

Mahkamah Konstitusi (MK), di tempat lain, mengumumkan penutupan gedung pada 17 Maret hingga 21 April 2020 dengan menerapkan proses kerja work 
from home serta pengajuan permohonan melalui simpel.mkri.id berdasarkan Surat Edaran Sekretaris Jenderal MK (SE Sekjen MK) Nomor 11 Tahun 2020 Tentang Upaya Pencegahan Penyebaran Corona Virus Diseases 2019 (Covid-19) Di Lingkungan Mahkamah Konstitusi. Kebijakan ini ditentukan tanpa memiliki batasan waktu yang diterbitkan pada 16 Maret 2020. Namun pada 31 Maret 2020 diterbitkan SE Sekjen MK Nomor 17 Tahun 2020 yang menentukan berlakunya keadaan yang sama hingga 21 April 2020. Kemudian diterbitkan kembali SE Sekjen MK Nomor 22 Tahun 2020 yang memperpanjang hingga 13 Mei 2020.

\section{Analisis dan Refleksinya bagi Kekuasaan Kehakiman di Indonesia}

Uraian perihal bagaimana administrasi peradilan dalam hal penerapan judicial emergency baik di Amerika Serikat dan Indonesia hingga saat Mei 2020, maka dapat ditinjau dari berbagai segi. Pertama, segi pengaturan. Amerika menggunakan undang-undang khusus mengenai judicial emergency yang memberikan kewenangan kepada berbagai pejabat pengadilan maupun Gubernur menetapkan keadaan darurat pengadilan. Sedangkan di Indonesia, undangundang kekuasaan kehakiman yang berlaku tidak memuat ketentuan mengenai bagaimana operasi kekuasaan kehakiman dalam keadaan darurat. Diaturnya kewenangan-kewenangan dan tindakan-tindakan yang dapat dilakukan dalam keadaan darurat melalui Judicial Emergency Act 2004 seperti di Amerika Serikat memberikan batasan dengan jelas sehingga menghindari adanya terhambatnya pemenuhan akses terhadap keadilan. Sedangkan di Indonesia terdapat beragam pengaturan di awal masa pandemi seperti di MA yang diatur melalui SE SEKMA kemudian berubah menjadi SEMA.

Kedua, segi koordinasi dan kewenangan. Apabila meninjau Judicial Emergency Act 2004 maka terdapat pembagian tugas yang jelas setiap satuan kerja di setiap tingkatan peradilan untuk melakukan tindakan yang dapat diantisipasi dari keadaan darurat yang ditetapkan dan berbagai hal yang perlu dipenuhi peradilan untuk para pencari keadilan. ${ }^{92}$ Sedangkan di Indonesia dimasa awal

92 Pasal 4 Judicial Emergency tahun 2004: Section 4. [Authority and Criteria for Declaring a Judicial Emergency.] (A) An authorized judicial official is authorized to declare the existence of a judicial emergency which shall be done by order either upon his or her own motion or upon motion by any interested person. The order shall state:

(1) The identity and position of the issuing authorized judicial official;

(2) The time, date, and place at which the order is executed; 
pandemi masih mengalami kegagapan dalam proses koordinasi kewenangan seperti yang terjadi dalam SE SEKMA No. 1 Tahun 2020 yang pada awalnya diberikan delegasi kepada satuan kerja untuk dapat membuat pengaturan teknis namun dengan harus berkoodinasi dengan Sekretaris Mahkamah Agung lalu memahami kesulitan untuk koordinasi semacam itu SEMA No. 1 Tahun 2020 memperbaikinya. Terlepas daripada itu, terdapat kesamaan antara di Amerika Serikat dan Indonesia yaitu memberikan seluruh kewenangan teknis dalam menyikapi keadaan darurat Covid-19 di masing-masing wilayah peradilan.

Ini menunjukan bahwa penggunaan Teknologi Informasi (TI) memainkan peran penting dalam mendukung dan memastikan tata kelola administrasi dan proses peradilan, terlepas dari berbagai respon kekuasaan kehakiman khususnya Indonesia terhadap Covid-19 melalui berbagai kebijakan. ${ }^{93}$ Teknologi Informasi dibutuhkan dalam proses pembuktian di pengadilan melalui penggunaan video, audio dalam sesi persidangan, pelaporan elektronik, video konferensi untuk saksi, dan penyimpanan file. Pendeknya, semua proses pengambilan keputusan di persidangan membutuhkan Teknologi Informasi.94 MA dan MK telah mengakomodasi ini dengan menggunakan teknologi untuk mereformasi administrasi peradilan. MK meluncurkan secara resmi Sistem Informasi MK yang terdiri dari Permohonan Online, Tracking Perkara, Anotasi Putusan MK, eMinutasi, e-BRPK, Kunjungan MK, Live Streaming, dan Layanan Persidangan Jarak Jauh (video conference), ${ }^{95}$ dan MA dengan memanfaatkan aplikasi e-court dan $e$ litigation. ${ }^{96}$ Hal sebagaiamana terurai menjadi sesuai dengan apa yang

(3) The jurisdiction or jurisdictions affected by the order;

(4) The nature of the emergency necessitating the order;

(5) The period or duration of the judicial emergency; and

(6) Any other information relevant to the suspension or restoration of court operations.

(B) An order declaring the existence of a judicial emergency shall be limited to an initial duration of not more than [30 days]; provided, however, that the order may be modified or extended for no more than [two periods] not exceeding [30 days] each. Any modification or extension of the initial order shall require information regarding the same matters set forth in subsection (A) of this section for the issuance of the initial order. (C) In the event the circumstances underlying the judicial emergency make access to the office of a clerk of court or a courthouse impossible or impractical, the order declaring the judicial emergency shall designate another facility, which is reasonably accessible and appropriate, for the conduct of court business.

93 Ibnu Sina Chandranegara, Kemerdekaan Kekuasaan Kebakiman Pasca Transisi Politik, Radjawali Press, Jakarta, 2019, hlm. 10.

${ }^{94}$ Dory Reiling, Technology for Justice How Information Technology..., Op. Cit., hlm. 14

95 Peraturan Mahkamah Konstitusi Nomor 18 Tahun 2009 Tentang Pengajuan Permohonan Elektronik (Electronic Filing) dan Pemeriksaan Persidangan Jarak Jauh (Video Conference)

96 Pan Mohamad Faiz mengemukakan, setidaknya ada empat hal yang tercermin dari pembaharuan tersebut. Pertama, para advokat yang akan berperkara harus sudah terdaftar datanya dalam sistem pendataan 
dikemukakan Richard Susskind bahwa profesi hukum dan persidangan perlu menyesuaikan dengan memanfaatkan teknologi menjadi sesuatu hal yang relevan. ${ }^{97}$

Apabila keadaan telah membaik perlu kiranya dalam kitab-kitab hukum acara mengatur mengenai hukum acara dalam keadaan bahaya. Apabila merujuk Jerman, melalui Zivilprozeßordung (disingkat ZPO atau Kitab Hukum Acara Perdata), ZPO telah mengatur mengenai hukum acara dalam keadaan darurat melalui Bab mengenai Interruption and suspension of the proceedings yang diatur dalam Pasal 239- 252 ZPO.98 Apabila dikaitkan dengan kondisi Covid-19, maka diatur dalam Pasal 245 ZPO yang menentukan "should, as the consequence of war or of any other event, the court cease its activities, the proceedings shall be interrupted for the duration of this situation. Kondisi ini memberikan ketegasan dalam konteks hukum acara pada keadaan interruption due to suspension of the administration of law. Selain itu, persoalan yang perlu mendapat perhatian ke depan adalah bagaimana kekuasaan kehakiman melaksanakan kekuasaannya apabila Pandemi Covid-19 berlangsung dalam waktu yang panjang. Implementasi sistem manajemen perkara secara online dan peradilan jarak jauh pada akhirnya perlu diatur dalam hukum acara beberapa peradilan atau mereformasinya menjadi satu hukum acara secara serentak. Selain daripada memuat ketentuan berkaitan dengan penetapan keadaan darurat peradilan, antisipasi seperti apa yang dapat dilakukan terhadap adanya keadaan darurat dan menjaga akses ke keadilan yang harus tetap dipenuhi dalam keadaan darurat di pengadilan.

elektronik. Kedua, pendaftaran perkara mulai diarahkan secara elektronik (online), termasuk untuk pembayaran biaya perkaranya. Ketiga, panggilan bagi para pihak akan dikirimkan secara elektronik berdasarkan database yang didaftarkan. Keempat, Salinan putusan atau penetapan pengadilan juga akan dikirimkan secara elektronik kepada para pihak paling lambat 14 hari sejak putusan atau penetapan diucapkan. Pan Mohamad Faiz, "MK dan ECourt Di Era Disruptif', Majalah Konstitusi No. 134, April 2018, hlm. 79-80.

${ }^{97}$ Richard Susskind, Tomorrow's Lanyers: An Introduction To Your Future, Oxford University Press, Oxford, 2013, hlm. 18

${ }^{98}$ Beberapa ketentuan yang diatur mengenai hukum acara dalam keadaan darurat di jerman: Interruption due to the death of a party, Interruption due to insolvency proceedings, Interruption due to a person coming under legal disability, Interruption due to reversionary succession, Resumption of proceedings in the case of a curator or an executor having been appointed for an estate, Interruption due to the loss of an attorney, Interruption due to suspension of the administration of law, Suspension in the event a party is represented by an attorney of record, Suspension in the event of interrupted communications, Procedure in the event of suspension, Effects of interruption and suspension, Form of resuming proceedings and notification, Stay of proceedings, Failure of both parties to comply with procedural rules; decision on the basis of the record as it stands, Appellate remedies available in the event of proceedings being suspended 


\section{Penutup}

Berdasarkan uraian di atas, maka kesimpulan untuk permasalahan pertama adalah bahwa keadaan darurat kesehatan di Amerika Serikat direspon kekuasaan kehakiman dengan menerapkan Judicial Emergency Act 2004 dan mendelegasikan kepada setiap pengadilan menentukan kebijakan daruratnya dan mendiferensiasi setiap kasus dan kebijakannya dalam situasi Pandemi Covid-19. Akibatnya, terjadi keberagaman kebijakan pengadilan di setiap jenjang dan negara bagian. Sedangkan di Indonesia tidak memiliki pengaturan serupa dalam undangundang kekuasaan kehakimannya sehingga keadaan darurat diatur secara otonom oleh masing-masing pelaku kekuasaan kehakiman. Akibatnya, mengalami kendala koordinasi kewenangan diawal masa darurat kesehatan akibat Pandemi Covid-19 Sedangkan untuk rumusan masalah kedua adalah perlunya diaturnya pengaturan yang memuat ketentuan berkaitan dengan penetapan keadaan darurat peradilan, antisipasi seperti apa yang dapat dilakukan terhadap adanya keadaan darurat dan menjaga akses ke keadilan yang harus tetap dipenuhi dalam keadaan darurat di pengadilan. Substansi pengaturan yang demikian perlu untuk dimuat dalam undang-undang kekuasaan kehakiman mendatang sebagai kebutuhan yang diperlukan untuk menjawab tantangan serupa di masa depan.

\section{Daftar Pustaka}

\section{Buku}

Chandranegara, Ibnu Sina, Kemerdekaan Kekuasaan Kehakiman Pasca Transisi Politik, Radjawali Press, Jakarta, 2019.

Redi, Ahmad dan Chandranegara (Editor), Ibnu Sina, Segi Hukum Implikasi Covid19, Prenada Kencana, Jakarta, 2020.

Hunter, Nan D., The Law of Emergencies Public Health and Disaster Management, Elsevier and Butterworth, New York, 2017.

Reiling, Dory, Technology for Justice How Information Technology can support Judicial Reform, Leiden University Press Law, Leiden, 2009.

Susskind, Richard, Tomorrow's Lawyers: An Introduction To Your Future, Oxford University Press, Oxford, 2013. 


\section{Jurnal}

Arde-Acquah, Phoebe E., "Salus Populi Suprema Lex Esto: Balancing Civil Liberties and Public Health Interventions in Modern Vaccination Policy," Washington University Journal Review, Vol 7, No. 337, 2015.

Bader, William D dan Williams, Frank J., "David Davis: Lawyer, Judge, and Politician in the Age of Lincoln", Roger Williams University Law Review Vol. 14, No 2, 2009.

Chandra, Siddharth, "Mortality from the influenza pandemic of 1918-1919 in Indonesia," Population Studies, Vol. 67, No. 2, 2013.

Fabbrini, Federico, "The Role Of The Judiciary In Times Of Emergency: Judicial Review Of Counter-Terrorism Measures In The United States Supreme Court And The European Court Of Justice." Yearbook of European Law, Vol 28, No. 1, 2009.

Hug, Walther. "The History of Comparative Law." Harvard Law Review, vol 45, no. $6,1932$.

Negretto, Gabriel L., "Government Capacities and Policy Making by Decree in Latin America: The Cases of Brazil and Argentina", Comparative Political Studies, Vol.37 No.5, June 2004.

Payne, J. Mark, Zovatto, Daniel, dan Díaz, Mercedes Mateo, Democracies in Development: Politics and Reform in Latin America, Washington: InterAmerican Development Bank, 2007.

Pimentel, David, "Reframing the Independence v. Accountability Debate: Defining Judicial Structure in Light of Judges' Courage and Integrity," Cleveland State Law Review Vol 51, No 1, 2015.

Rheinstein. Max, "Comparative Law - Its Functions, Methods and Usages," Arkansas Law Review, Vol. 22, No. 3, 1968.

Sheeran, Scott P., "Reconceptualizing States of Emergency under International Human Rights Law: Theory, Legal Doctrine, and Politics", Michigan Journal of International Law, Vol. 34, 491, 2013.

\section{Makalah}

Chandranegara, Ibnu Sina, Diantara yang terbaik dan buruk dalam Merespon Covid-19 di Asia Tenggara, Makalah disampaikan dalam Seminar Nasional (via Zoom) "PSBB: Tanya Apa? Yang diselenggarakan Universitas Negeri Surabaya, tanggal 4 Mei 2020.

Fox, Natalie, Firlus, Jakub dan Mikuli, Piotr, Models of Courts Administration: An Attempt at a Comparative Review, Riset Project No. 2016/21/B/HS5/00445 yang dibiayai oleh National Science Centre (Polandia), 2017. DOI: 10.13140/RG.2.2.12610.58562 
Majalah

Faiz, Pan Mohamad, "MK dan E-Court Di Era Disruptif", Majalah Konstitusi No. 134, April 2018

\section{Peraturan Perundang-Undangan}

Undang-Undang Dasar Negara Republik Indonesia Tahun 1945

Judicial Emergency Act 2004

Zivilprozeßordung, 2013

Peraturan Mahkamah Agung No 1 Tahun 2019 tentang Administrasi Perkara di Pengadilan secara Elektronik.

Peraturan Mahkamah Konstitusi Nomor 18 Tahun 2009 Tentang Pengajuan Permohonan Elektronik (Electronic Filing) dan Pemeriksaan Persidangan Jarak Jauh (Video Conference)

Surat Keputusan Kepala BNPB Nomor 9.A. tahun 2020 tentang Penetapan Status Keadaan Tertentu Darurat Bencana Wabah Penyakit akibat Virus Corona di Indonesia

Surat Keputusan Kepala BNPB Nomor 13.A tahun 2020 tentang Perpanjangan Status Keadaan Tertentu Darurat Bencana Wabah Penyakit akibat Virus Corona di Indonesia

Surat Edaran Sekretaris Mahkamah Agung (SE SEKMA) No. 1 Tahun 2020 berupa upaya pencegahan penyebaran COVID-19 di lingkungan Mahkamah Agung dan badan peradilan di bawahnya

\section{Sumber Digital}

http:/ / courts.state.va.us/news/items /2020_0327_scv_order_extending_declarati on_of_judicial_emergency.pdf, diakses pada tanggal 5 April 2020

http:/ / nmijudiciary.com/wp-content/uploads/2020/04/Covid-Order-No21.pdf, diakses pada tanggal 5 April 2020

http:/ /tncourts.gov/sites/default/files/docs/order_-_2020-03-25t120936.486.pdf, diakses pada tanggal 5 April 2020

http:/ / www.alacourt.gov/docs/Administrative\%20Order\%20No.\%205.pdf, diakses pada tanggal 5 April 2020

http:/ / www.azcourts.gov/Portals/22/admorder/Orders20/2020-48.pdf, diakses pada tanggal 5 April 2020

http:/ / www.courts.state.wy.us/wp-content/uploads/2020/04/COVID-19-

Order.Extend.temp_.plan_.pdf, diakses pada tanggal 5 April 2020

http:/ / www.courts.wa.gov/content/publicUpload/Supreme\%20Court\%20Order s/Supreme $\% 20$

Court $\% 20$

Emergency\%20Order\%20re\%20CV19\%20031820.pdf, diakses pada tanggal 5 April 2020 
http:/ / www.courtswv.gov/covid19/JudicialEmergencyDeclaredAmendedOrder 4-3-20.pdf, diakses pada tanggal 5 April 2020

http:/ / www.mncourts.gov/mncourtsgov/media/CIOMediaLibrary / Administra tive-Order-Continuing-the-Operations-of-the-Courts.pdf, diakses pada tanggal 5 April 2020

http:/ / www.oscn.net/images/news/SCAD-2020-24.pdf, diakses pada tanggal 5 April 2020

http://www.pacourts.us/assets/files/page-1305/file-8910.pdf, diakses pada tanggal 5 April 2020

http://www.supremecourt.ohio.gov/coronavirus/default.asp, diakses pada tanggal 5 April 2020

https:/ / courts.delaware.gov/forms/download.aspx?id=120328, diakses pada tanggal 5 April 2020

https://courts.illinois.gov/SupremeCourt/Announce/2020/040320.pdf, diakses pada tanggal 5 April 2020

https: / courts.michigan.gov/Courts/MichiganSupremeCourt/rules/court-rulesadmin-matters / Administrative\%20Orders/2020-08_2020-03-

15_FormattedOrder_AO2020-1.pdf, diakses pada tanggal 5 April 2020

https: / / courts.ms.gov/appellatecourts / docket/sendPDF.php?f=700_490703.pdf $\& c=91465 \& a=N \& s=2$, diakses pada tanggal 5 April 2020

https:/ / courts.mt.gov/Portals/189/docs/COVID-19\%203-17.pdf, diakses pada tanggal 5 April 2020

https:/ / isc.idaho.gov/EO/ISC-Emergency-Order-Ammended.pdf, diakses pada tanggal 5 April 2020 